ISSN 0103-8478

\title{
Mineralogy, zinc kinetic adsorption and sequential extraction of contaminated soil in Manaus, Amazon
}

\author{
Mineralogia, cinética de adsorção e extração sequencial de \\ zinco de um solo contaminado em Manaus, Amazônia, Brazil
}

\author{
Wamber Broni de Souza ${ }^{I}$ Genilson Pereira Santana ${ }^{I I}$
}

\section{ABSTRACT}

Zinc is a heavy metal that enters the environment as consequence of both natural and anthropogenic activities. The association of the soil geochemical fractions and adsorption kinetics were studied to evaluate the behavior of the $\mathrm{Zn}$ in a contaminated Utisol soil. The contaminated soil samples were collected at depth 0-20, 20-40, 40-60, and 60-80 cm into the Manaus Industrial District (MID) region. The study was performed in soil fractions at $50 \mu \mathrm{m}$ being the samples submitted to sequential extraction, batch experiments, $X$-ray diffraction (XRD) and Fourier transformed infrared spectroscopy (FT-IR). The adsorption kinetics was fitted according to Lagergren equation. The physical and chemical proprieties of soil showed that organic matter has low cation adsorption capacity and the existence of kaolinite poorly ordered, monoclinic and mixed with others mineral. The kinetics experiments performed indicated that the $\mathrm{Zn}$ is adsorbed by sorption process most probably with the formation of two bidentate surfaces. The Zn contents are above established by CETESB (reference value $60 \mathrm{mg} \mathrm{kg}^{-1}$ ) being observed remarkable differences between exchangeable and residual fraction.

Key words: Manaus Industrial District, utisol soil, kaolinite, XRD, FT-IR

\section{RESUMO}

O zinco é um metal pesado que é introduzido no ambiente como consequências de atividades naturais e antrópicas. A associação das frações geoquímicas do solo e a cinética de adsorção foram estudadas para avaliar o comportamento do $\mathrm{Zn}$ em um Argissolo Vermelho-Amarelo. As amostras de solo contaminado foram coletadas nas profundidades de 0-20, 20 40, 40-60 e 60-80cm na região do Distrito Industrial de Manaus (MID). O estudo foi realizado nas frações do solo $50 \mu \mathrm{m}$, sendo as amostras submetidas à extração sequencial, experimentos de adsorção, difração de raios $X(D R X)$ e espectroscopia no infravermelho com transformada de Fourier (IV-TF). A cinética de adsorção foi ajustada de acordo com a equação de Lagergren. As propriedades físicas e químicas do solo mostram que a matéria orgânica tem baixa capacidade de adsorção e a existência de caulinita pobremente ordenada, monoclina e misturada com outros minerais. Os experimentos de cinética indicaram que o Zn é adsorvido por um processo de sorção, muito provavelmente, parecido com a formação de superfícies bidentadas. A quantidade de Zn está acima do estabelecido pela CETESB (valor de referência de $60 \mathrm{mg} \mathrm{kg}^{-1}$ ), sendo observada notável diferença entre as frações trocável e residual.

Palavras-chave: Distrito Industrial de Manaus, utisolo, caulinita, $D R X, I V-T F$.

\section{INTRODUCTION}

In elevated concentration, the $\mathrm{Zn}$ can pose long-term risks for soil fertility and environment, affecting the microbiologic activities and increasing the phytotoxicity of the ecosystem. Zinc bioaccumulation is a health problem in which the world health organization (WHO) and Brazil's Ministry of Health (Law 2914/2011) regulated the concentration of $5.0 \mathrm{mg} \mathrm{L}^{-1}$ as maximum acceptable in drinking water. In fact $\mathrm{Zn}$ which has widely released it on the soil, is known as a heavy metal of the Priority Pollutants list (ATSDR, 2013).

In the soil, $\mathrm{Zn}$ reacts naturally with clay minerals, organic matter and oxides of metals such as iron and manganese (ABAT et al., 2012). As is known, soils serve as sinks being the clay minerals and organic contents important components for the

\footnotetext{
Instituto de Ciências Sociais, Educação e Zootecnia (ICSEZ), Universidade Federal do Amazonas (UFAM), 69152-000, Parintins, AM, Brasil. E-mail: wambersa@ufam.edu.br. Autor para correspondência.

IIDepartamento de Química, Instituto de Ciências Exatas (ICE), UFAM, Manaus, AM, Brasil.
} 
control of the sorption/retention of contaminants such as heavy metals (ARIAS \& SEN, 2009). Furthermore, colloidal constituents such as kaolinite are the components responsible for the chemical behavior of $\mathrm{Zn}$ in soil (WANG \& Li, 2011). Specifically the kaolinite surface is the base of several phenomena, especially adsorption, which occur at the solidsolution interface, and are influenced by soil solution properties such as the ionic strength; $\mathrm{pH}$ values (ZHU, et al., 2012).

The study of the kinetics and the thermodynamics of the adsorption process provide important information on heavy metal phytotoxicity. Previous researchers have provided numerous kinetic models used to describe sorption processes. These include first-order, and second-order reversible ones, and first-order and second-order, irreversible ones, pseudo-first-order and pseudo-second-order ones based on the solution concentration (ADEBOWALE et al., 2008). The association in soil fractions as well as the kinetic adsorption capacity was studied in aim to predict the behavior of $\mathrm{Zn}$ in a polluted Utisol soil by galvanic industry from MID region that present high levels of heavy metal in its ecosystem.

\section{MATERIAL AND METHODS}

\section{Sampling sites}

Contaminated Utisol soil samples were collected in three sites sampling from the Manaus Industrial District-MID: IG03 (S 306’33,16"; W 59॰57'33,75”), IG04 (S 306'64”; W59 57'52,51”) and IG05 (S 3'06'53,99';W59 58'06,78'), in along of the profile: $0-20,20-40,40-60$, and $60-80 \mathrm{~cm}$. Each soil sampling was subdivided in 4 subsamples. Soil samples were air-dried under room temperature for 24 hours. Approximately $1.0 \mathrm{~kg}$ of the soil samples were then passed through a $2 \mathrm{~mm}$ stainless steel sieve in order to obtain the fine soil fraction $(<2 \mathrm{~mm})$. The sand, silt, clay fractions, cation $\left(\mathrm{Zn}^{2+}\right)$, organic matter contents, $\mathrm{CEC}$ and $\mathrm{C} / \mathrm{N}$ values were determined by recommendation EMBRAPA (1997) (Table 1).

The fine soil was dispersed in water, sieved to separate the fraction $50 \mu \mathrm{m}$ and then dried at room temperature. This fraction was used in XRD, FT-IR and batch experiments.

\section{X-Ray diffraction}

The X-ray diffraction was obtained in a Geigerflex diffractometer D/max Series B (Rigaku) equipped with monochromator graphite and copper tube. Soil Samples $<2 \mathrm{~mm}$ were triturated and pressed into an aluminum sample holder, and measurements were made from 5 to $70^{\circ}(2 \theta)$ at steps of $0.02^{\circ}$ with a counting of 0.6 step $^{-1}$.

\section{FT-IR}

The infrared spectra were recorded range 4000 to $400 \mathrm{~cm}^{-1}$ on a Perkin Elmer spectrophotometer model Spectrum 2000 and 20 scans were performed with spectral resolution of $4 \mathrm{~cm}^{-1}$. The pellets containing about $1.0 \mathrm{mg}$ of fraction $50 \mu \mathrm{m}$ and $100 \mathrm{mg}$ of $\mathrm{KBr}$ were dried at $100^{\circ} \mathrm{C}$ for 24 hours to eliminate any existing moisture.

\section{Kinetics experiments}

The experiments were performed by adding portions of $1.000 \mathrm{~g}$ of the $0.053 \mathrm{~mm}$ fraction samples and $20 \mathrm{~mL}$ of $\mathrm{Zn} 50 \mathrm{mg} \mathrm{L}^{-1}$ in 12 flasks in all soil samples (fractions $<2 \mathrm{~mm}$ ). The flasks were stirred during $480 \mathrm{~min}$. and after intervals of $30 \mathrm{~min}$ one flask was removed and filtered in Millipore $(0.45 \mu \mathrm{m}$ and diameter $47 \mathrm{~mm})$. The $\mathrm{Zn}$ concentration was determined by FAAS (Spectrometer GBC AAS932 plus) using an air-acetylene flame and standard reagent certificates (SpecSol) with concentration

Table 1 - Physical and chemical properties of the Utisol soil contaminated from Manaus Industrial District-MID

\begin{tabular}{|c|c|c|c|c|}
\hline & $00-20$ & $20-40$ & $40-60$ & $60-80$ \\
\hline Sand $\left(\mathrm{g} \mathrm{kg}^{-1}\right)$ & $809 \pm 2$ & $780 \pm 9$ & $801 \pm 0.3$ & $750 \pm 5$ \\
\hline Silt $\left(\mathrm{g} \mathrm{kg}^{-1}\right)$ & $24.5 \pm 0.1$ & $40.0 \pm 0.1$ & $23.0 \pm 0.6$ & $19.0 \pm 0.3$ \\
\hline Clay $\left(\mathrm{g} \mathrm{kg}^{-1}\right)$ & $157.0 \pm 0.4$ & $179.5 \pm 0.6$ & $182.0 \pm 0.4$ & $222.0 \pm 0.7$ \\
\hline $\mathrm{pH}_{\mathrm{KCl}}$ & $5.19 \pm 0.11$ & $5.08 \pm 0.72$ & $5.37 \pm 0.34$ & $5.18 \pm 0.92$ \\
\hline $\mathrm{pH}_{\mathrm{H} 20}$ & $5.19 \pm 0.58$ & $5.34 \pm 0.07$ & $5.90 \pm 0.95$ & $5.63 \pm 0.38$ \\
\hline $\operatorname{CEC}\left(\mathrm{cmol}_{\mathrm{c}} \mathrm{kg}^{-1}\right)$ & $3.05 \pm 0.66$ & $4.24 \pm 0.46$ & $4.55 \pm 0.69$ & $1.48 \pm 0.24$ \\
\hline Organic matter $\left(\mathrm{g} \mathrm{kg}^{-1}\right)$ & $11.7 \pm 0.8$ & $1.89 \pm 0.03$ & $17.6 \pm 0.9$ & $12.8 \pm 0.2$ \\
\hline $\mathrm{Zn}^{2+}\left(\mathrm{mg} \mathrm{kg}^{-1}\right)$ & $10.34 \pm 0.36$ & $8.28 \pm 0.07$ & $12.85 \pm 0.42$ & $10.77 \pm 0.25$ \\
\hline $\mathrm{C} / \mathrm{N}$ & $17.30 \pm 0.23$ & $21.10 \pm 0.34$ & $19.95 \pm 0.14$ & $17.70 \pm 0.90$ \\
\hline
\end{tabular}


at $1.000 \pm 0.003 \mathrm{mg} \mathrm{g}^{-1}$. The flame and lengths waves were set for each element according to the instrumental manual. For all elements, the readings were made only with calibration curves presenting $\mathrm{r}^{2} \geq 0.99$. The $\mathrm{Zn}$ solution was adjusted to $\mathrm{pH}$ value $5.00 \pm 0.5$ with $\mathrm{HCl} / \mathrm{NaOH}$ that is the variation of the value found in the studied soil samples (Table 1). The data of each experiment were obtained in triplicate. The pseudo-second-order model of the Lagergren equation was chosen based on their applicability and recommendation found in several studies on soils (ADEBOWALE et al., 2008). The pseudo-secondorder equation given below was used:

$$
q_{t}=k q_{e}^{2} t
$$

The differential equation is as follows:

$\frac{d q_{i}}{d t}=\frac{k\left(q_{e}+q_{i}\right)}{1+k_{f}}$

Integrating for the boundary conditions $t=0$ to $t=t$

$$
\frac{1}{q_{e}-q_{t}}=\frac{1}{q_{e}}+k_{t}
$$

When this is linearized, it gives

$$
\frac{t}{q_{t}}=\frac{1}{k_{2} q_{e}^{2}}+\frac{t}{q_{e}}
$$

Where $q_{e}$ is the amount of $\mathrm{Zn}^{2+}$ adsorbed at equilibrium (mg L-1), $q_{t}$ amount of $\mathrm{Zn}^{2+}$ adsorbed at time $t\left(\mathrm{mg} \mathrm{g}^{-1}\right)$ and $k_{2}$ is the rate constant of the pseudo-second-order sorption ( $\left.\mathrm{g} \mathrm{mg}^{-1} \mathrm{~min}\right)$.

The constant $k_{2}$ is used to calculate initial sorption rate $h$, at $t \rightarrow 0$, as follows

$h=k_{2} q_{2}^{2}$

Sequential extraction

The sequential extraction used by fine soil $(50 \mu \mathrm{m})$ was the same as what was recommended by TESSIER et al., (1979). The extract proceed was carried out at room temperature, in block digestion (Marconi, model MA4025-SCR), with agitation in shaker (Marconi, model MA570), and extraction of the analytical-reagents grade.

\section{RESULTS AND DISCUSSION}

It has been known for a long time that the clay and organic matter content of soils control the CEC. One of the most widely used indices for maturity of organic waste that is the $\mathrm{C}: \mathrm{N}$ ratio in all soil samples is less than 20 indicating an advanced degree of stabilization as well as an equilibrium between mineralization and immobilization process during organic matter decomposition (Table 1). The organic matter into Utisol soil has low adsorption capacity and consequently its contribution for the adsorption of the cations is relatively low. On the other hand, the $\Delta \mathrm{pH}\left(\mathrm{pH}_{\mathrm{KCl}}-\mathrm{pH}_{\mathrm{H} 2 \mathrm{O}}\right)$ values in all samples which indicates the predominance of negative charges.

Despite of the table 1 presents high iron contents X-ray diffraction patterns showed the presence of only kaolinite and quartz in all soil samples (Figure 1). In a particular reference to the reflections they indicate that the kaolinite (clay mineral) has low crystallinity and/or it is non-ordered. Furthermore, it possible to observe the relationship between the intensity of the reflections $d_{131}$ and $d_{1} \overline{3}_{1}$, an important feature observed in $\mathrm{XRD}$, which suggest the existence of a monoclinic kaolinite.

The FT-IR spectra in all soil samples show only bands relatives to kaolinite (Figure 1). In 3669 , $3653,3631 \mathrm{~cm}^{-1}$ exist intense bands of absorption corresponding to the vibrations $v_{1}, v_{2}$ and $v_{3} \mathrm{O}-\mathrm{H}$, respectively. The lack of resolution of the vibration $v_{2}$ point to the existence of kaolinite with a very poor level of planning evidenced by the increased intensity $v_{4}$ in relation to $v_{1}$. PROST et al. (1989) argue that the FT-IR spectrum as described above could be an indicative of the existence of dickite and nacrite instead of a disordered kaolinite. However XRD did not reveal specifically the existence of these minerals but the possibility of having a mixture of minerals.

Bands occur at $1115 \mathrm{~cm}^{-1}$ Si-O, 1036 and $1009 \mathrm{~cm}^{-1}$ on vibration $\mathrm{Si}-\mathrm{O}-\mathrm{Si}$ and 937 and $915 \mathrm{~cm}^{-1}$ $\mathrm{O}-\mathrm{H}$. The asymmetry of at least 1.15 between the bands 1115 and $915 \mathrm{~cm}^{-1}$, as well as among $v_{1}-v_{4}$, points to an intercalate kaolinite. Therefore, FT-IR spectra suggest that kaolinites into Utisol soil are intercalated by cations. However their reactivity is probably low because of the intercalation process that is better for well-ordered kaolinite than the poorly ordered kaolinite. The kaolinite crystalline structure observed in this work is supported by MELO et al. (2001) that claim in Brazil the existence of kaolinites with relatively poor crystal order, with elongated, subspherical large aggregated and rounded forms as well as high stability.

The first-order reaction model was used to check all the results but the correlation coefficient is not high. However the rate law for a pseudo-second order could be fixed with very high correlation coefficient. According to GUERRA et al. (2010) this result depends on the control of the rate of reaction of an adsorption reaction. For example adsorption cation on Amazon kaolinite surface is better adjusted to the experimental kinetic data in constant

Ciência Rural, v.44, n.5, mai, 2014 


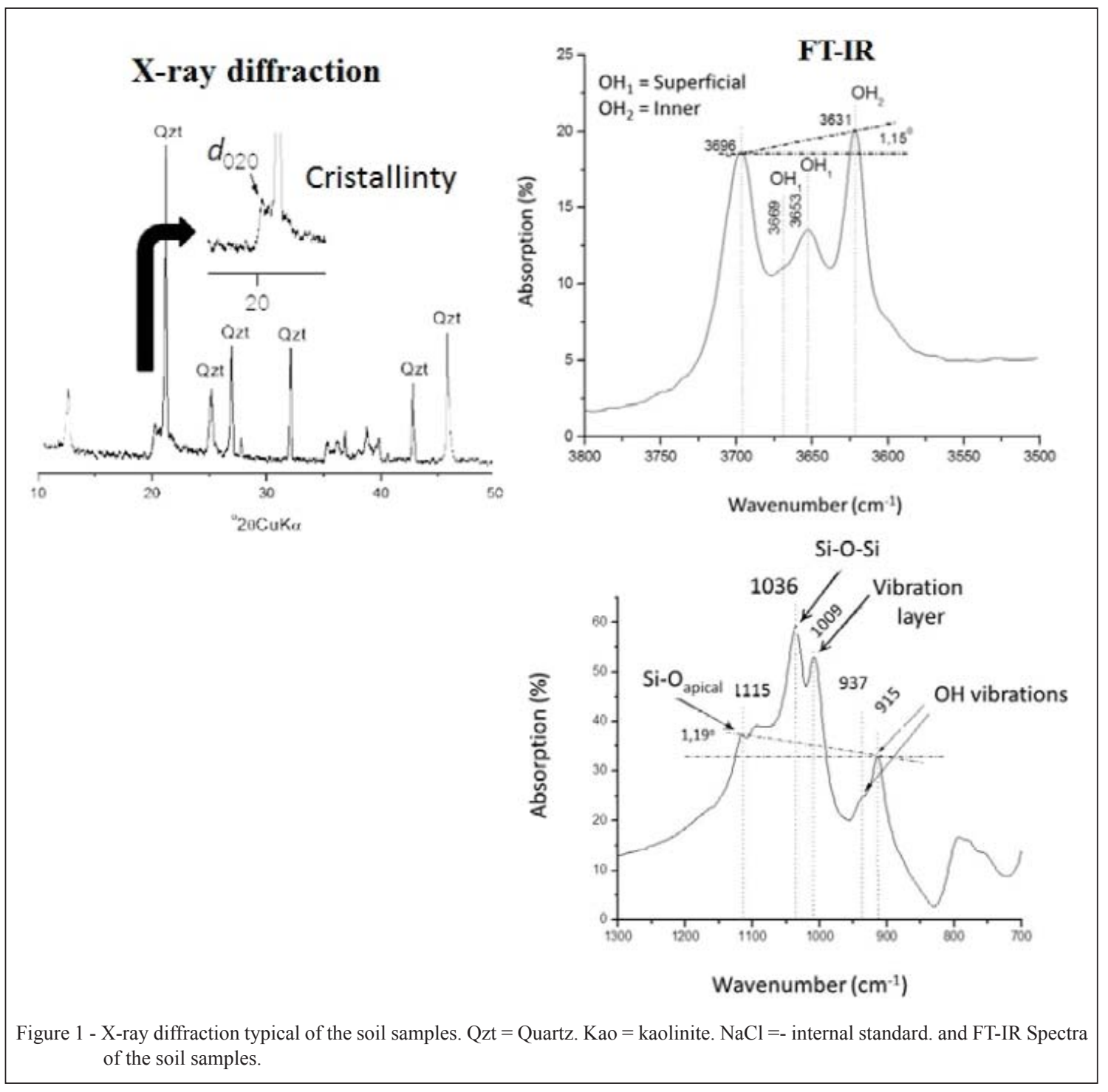

temperature and monitoring the amount adsorbed with time. The sorption of $\mathrm{Zn}^{2+}$ ion onto Utisol soil could be as pseudo-second order process rather than first order. The fitting date for $t / q_{t}$ versus time $t$ for $\mathrm{Zn}^{2+}$ adsorption at different depth in the sampling sites IG03, IG04 and IG05, all parameters including the linear regression coefficients, $\mathrm{R}^{2}$, the initial adsorption rate, $\mathrm{h}$, the pseudo-second-rate constant $k_{2}$ and equilibrium sorption capacity, $q_{e}$, are given in the table 2. The linear regression coefficients suggest two form of metal uptake processes: i) chemisorption and ii) more than one-step for the $\mathrm{Zn}^{2+}$ sorption.

As the experiment kinetics was carried out in $\mathrm{pH}$ values at $5.0 \pm 0.5$ (values of the soil samples) the $\mathrm{Zn}^{2+}$ should be present in the forms of $\mathrm{Zn}^{2+}, \mathrm{Zn}(\mathrm{OH})^{+}$, and $\mathrm{Zn}(\mathrm{OH})_{2(\mathrm{~s})}$. At $\mathrm{pH}$ value $~ 5.0$, the solubility of $\mathrm{Zn}(\mathrm{OH})^{+}$and $\mathrm{Zn}(\mathrm{OH})_{2(\mathrm{~s})}$ is high and therefore, the $\mathrm{Zn}^{2+}$ is the specie that take part sorption process (SRIVASTAVA et al., 2005).

The main reason for this is due to the vertical stacking of kaolinite lattices which exposes a large vertical or edge surface area compared to the horizontal or planar surface area. Furthermore, the adsorption which takes place by this electrostatic mechanism is thermodynamically more stable and easier to adsorb than the free metal cation (USMAN, 2007). It occurs as a result of the kaolinite crystalline structure being poorly ordered and its negative charge depending on disruption of the structure at the edges particles.

Table 3 shows that the results found by applying sequential extraction methods to the soil samples. The values included are means of the three replicates with relative standard deviation ranged from 1 to $10 \%$ suggesting good repeatability. The 
Table 2 - Pseudo-second-order kinetic parameters. $q_{e}=\mathrm{Zn}^{2+}$ adsorbed at equilibrium, $q_{t} \mathrm{Zn}^{2+}$ adsorbed at time $t$ and $k_{2}=$ pseudo-second-order rate constant.

\begin{tabular}{|c|c|c|c|c|c|c|}
\hline Sampling & Depth $(\mathrm{cm})$ & $q_{e}\left(\mathrm{mg} \mathrm{g}^{-1}\right)$ & $k_{2}$ & -1) -------. & $\mathrm{Y}=\mathrm{AX}+\mathrm{B}$ & $\mathrm{R}^{2}$ \\
\hline \multirow{4}{*}{ IG03 } & $00-20$ & 0.8496 & -0.1970 & -0.1422 & $\mathrm{t} / \mathrm{qt}=1.1769 \mathrm{t}-7.0286$ & 0.9934 \\
\hline & $20-40$ & 0.5154 & -0.1726 & -0.0458 & $\mathrm{t} / \mathrm{qt}=1.9401 \mathrm{t}-21.7984$ & 0.9888 \\
\hline & $40-60$ & 0.4007 & 3.8773 & 0.6227 & $\mathrm{t} / \mathrm{qt}=2.4953 \mathrm{t}+1.6059$ & 0.9921 \\
\hline & $60-80$ & 0.5517 & 0.1264 & 0.0384 & $\mathrm{t} / \mathrm{qt}=1.8123 \mathrm{t}+25.9774$ & 0.9844 \\
\hline \multirow{4}{*}{ IG04 } & $00-20$ & 0.4355 & -0.1148 & -0.0217 & $\mathrm{t} / \mathrm{qt}=2.2957 \mathrm{t}-45.9042$ & 0.9875 \\
\hline & $20-40$ & 0.4876 & -0.1833 & -0.0435 & $\mathrm{t} / \mathrm{qt}=2.0505 \mathrm{t}-22.9372$ & 0.9894 \\
\hline & $40-60$ & 0.4465 & 0.4664 & 0.0930 & $\mathrm{t} / \mathrm{qt}=2.2392 \mathrm{t}+10.7487$ & 0.9847 \\
\hline & $60-80$ & 0.4355 & -0.1148 & -0.0217 & $\mathrm{t} / \mathrm{qt}=2.2957 \mathrm{t}-45.9042$ & 0.9875 \\
\hline \multirow{4}{*}{ IG05 } & $00-20$ & 0.3340 & -0.1795 & -0.0200 & $\mathrm{t} / \mathrm{qt}=2.9938 \mathrm{t}-49.9210$ & 0.9719 \\
\hline & $20-40$ & 0.3310 & 0.5094 & 0.0558 & $\mathrm{t} / \mathrm{qt}=3.0207 \mathrm{t}+17.9131$ & 0.9755 \\
\hline & $40-60$ & 0.2361 & 0.2230 & 0.0124 & $\mathrm{t} / \mathrm{qt}=4.2341 \mathrm{t}+80.37$ & 0.9821 \\
\hline & $60-80$ & 0.2733 & -1.7264 & -0.1290 & $\mathrm{t} / \mathrm{qt}=3.6577 \mathrm{t}-7.7490$ & 0.9912 \\
\hline
\end{tabular}

greatest values in the relative standard deviations were usually obtained in the phases and $\mathrm{Zn}$ present in the soil with lowest concentrations, especially if they are near the limits of detection of the analytical methods used. The $\mathrm{Zn}$ total contents (the sum of the steps of the sequential extraction) in all soil samples are above those established by CETESB $\left(60 \mathrm{mg} \mathrm{kg}^{-1}\right)$ for soils from State of São Paulo.

The presence of $\mathrm{Zn}$ in all operational fractions indicates that this metal is distributed between the bioavailable/mobile pool (exchangeable, carbonates, oxidisable and reducible fractions) and residual fraction, representing 10-60 and 90-40\% respectively. Furthermore the $\mathrm{Zn}$ content into each selective treatment fraction varied according to sampling site mainly in the exchangeable and residual fractions. It was observed a remarkable difference in the amount of $\mathrm{Zn}$ in the exchangeable fraction depending on depth and sampling site.

The $\mathrm{Zn}$ content into each sequential extraction fraction varied according to sampling site mainly in those fractions corresponding to the operationally defined as exchangeable and residual. The following order IG04>IG05 $>$ IG03 is observed for exchangeable fraction. Depending on changes of the redox condition mainly Eh the $\mathrm{Zn}$ can be easily

Table 3 - Zn contents ( $\mathrm{mg} \mathrm{kg}^{-1}$ ) extracted of IG03, IG04 and IG05 by sequential extraction proposed by Tessier et al. (1979) from Manaus Industrial District-MID.

\begin{tabular}{|c|c|c|c|c|c|c|}
\hline Sampling & Depth $(\mathrm{cm})$ & $\begin{array}{l}\text { Exchangeable } \\
\text { Fraction }\end{array}$ & $\begin{array}{l}\text { Bound to } \\
\text { Carbonate }\end{array}$ & $\begin{array}{l}\text { Bound to Iron and } \\
\text { Manganese }\end{array}$ & $\begin{array}{l}\text { Bound to Organic } \\
\text { Matter }\end{array}$ & Residual fraction \\
\hline \multirow{4}{*}{ IG03 } & $00-20$ & $4.0 \pm 0.5$ & $4.6 \pm 0.3$ & $1.10 \pm 0.03$ & $7.4 \pm 0.5$ & $143.2 \pm 3.4$ \\
\hline & $20-40$ & $2.9 \pm 0.1$ & $3.2 \pm 0.1$ & $1.10 \pm 0.02$ & $9.1 \pm 0.2$ & $147.1 \pm 1.6$ \\
\hline & $40-60$ & $4.6 \pm 0.2$ & $3.9 \pm 0.7$ & $4.00 \pm 0.08$ & $4.1 \pm 0.6$ & $150.3 \pm 8.1$ \\
\hline & $60-80$ & $5.3 \pm 0.3$ & $3.7 \pm 0.4$ & $1.10 \pm 0.07$ & $12.9 \pm 0.9$ & $161.4 \pm 7.0$ \\
\hline \multirow{4}{*}{ IG04 } & $00-20$ & $75.3 \pm 0.7$ & $15.6 \pm 0.9$ & $13.30 \pm 0.06$ & $29.4 \pm 0.8$ & $104.1 \pm 5.8$ \\
\hline & $20-40$ & $51.8 \pm 0.1$ & $13.1 \pm 0.4$ & $9.70 \pm 0.08$ & $31.5 \pm 0.9$ & $100.3 \pm 8.4$ \\
\hline & $40-60$ & $105.0 \pm 0.7$ & $19.7 \pm 0.8$ & $11.70 \pm 0.16$ & $18.9 \pm 0.1$ & $105.6 \pm 1.6$ \\
\hline & $60-80$ & $77.0 \pm 0.3$ & $12.6 \pm 0.2$ & $8.90 \pm 0.08$ & $13.7 \pm 0.1$ & $102.3 \pm 8.4$ \\
\hline \multirow{4}{*}{ IG05 } & $00-20$ & $25.9 \pm 0.9$ & $7.4 \pm 0.8$ & $4.20 \pm 0.07$ & $10.9 \pm 0.3$ & $99.1 \pm 7.2$ \\
\hline & $20-40$ & $28.3 \pm 0.7$ & $11.4 \pm 1.0$ & $5.30 \pm 0.71$ & $17.0 \pm 0.4$ & $90.8 \pm 7.1$ \\
\hline & $40-60$ & $28.3 \pm 0.2$ & $7.5 \pm 0.6$ & $5.00 \pm 0.71$ & $16.0 \pm 0.9$ & $107.6 \pm 7.1$ \\
\hline & $60-80$ & $24.6 \pm 0.9$ & $7.0 \pm 0.5$ & $4.50 \pm 0.24$ & $17.5 \pm 0.8$ & $113.1 \pm 2.4$ \\
\hline
\end{tabular}


released into the environment (TESSIER et al., 1979). Furthermore, the kinetic findings show the Utisol soil has low capacity of the adsorption and consequently the $\mathrm{Zn}$ mobilization is high.

Despite of the Utisol soil from Manaus have low carbonate content, the acid-extractable fraction, operationally defined as bound to carbonates, was high and varied depending on sampling site. Zinc may be present in this fraction as co-precipitated with other isostructural carbonates, e.g. siderite $\left(\mathrm{FeCO}_{3}\right)$ commonly found in the ore gangue (ETTLER et al., 2007). It imply that an appreciable contents of $\mathrm{Zn}$ would have been remobilized becoming readily available following a slight lowering of $\mathrm{pH}$.

\section{CONCLUSION}

The $\mathrm{C}: \mathrm{N}$ ratio indicated the presence of organic matter with low cation adsorption capacity. The XRD and FT-IR indicate the existence of kaolinite poorly ordered, monoclinic, mixed with others mineral, such as halloysite, dickite, nacrite, quartz, illite, feldspars. The kinetics data were better adjusted by pseudo-second order equation for Lagergren model. The adsorption kinetics showed the $\mathrm{Zn}$ is adsorbed by sorption process most probably with the formation of two bidentate surface complexes. The $\mathrm{Zn}$ contents are above established by CETESB being observed remarkable differences between exchangeable and residual fraction.

\section{REFERENCES}

ABAT, M. et al. Adsorption and desorption of copper and zinc in tropical peat soils of Sarawak, Malaysia. Geoderma, v.176, p.58-63, 2012. Available from: <http://www.sciencedirect.com/ science/article/pii/S001670611200050X $>$. Accessed: Jan. 28, 2013. doi: 10.1016/j.geoderma.2012.01.024.

ADEBOWALE, K.O. et al. Kinetic and thermodynamic aspects of the adsorption of $\mathrm{Pb}^{2+}$ and $\mathrm{Cd}^{2+}$ ions on tripolyphosphatemodified kaolinite clay. Chemical Engineering Journal, v.136, p.99-107, 2008. Available from: <http://dx.doi.org/10.1016/j. cej.2007.03.012>. Accessed: Jan. 28, 2013. doi: 10.1016/j. cej.2007.03.012.

ARIAS, F.; SEN, T.K. Removal of zinc metal ion $\left(\mathrm{Zn}^{2+}\right)$ from its aqueous solution by kaolin clay mineral: A kinetic and equilibrium study. Colloids and Surface A: Physicochemical and Engineering Aspects, v.348, p.100-108, 2009. Available from: <http://dx.doi. org/10.1016/j.colsurfa.2009.06.036>. Accessed: Jan. 28, 2013. doi: 10.1016/j.colsurfa.2009.06.036.

AGENCY FOR TOXIC SUBSTANCES AND DISEASE REGISTRY (ATSDR). Priority List of Hazardous Substances. Available from: <http://www.atsdr.cdc.gov/SPL/index.html > Accessed: Apr. 17, 2013.
EMPRESA BRASILEIRA DE PESQUISA AGROPECUÁRIA (EMBRAPA). Centro Nacional de Pesquisa de Solos. Manual de métodos de análises de solo. Rio de Janeiro, 1997. 212p.

ETTLER, V. et al. Geochemical and $\mathrm{Pb}$ isotopic evidence for sources and dispersal of metal contamination in stream sediments from the mining and smelting district of Príbram. Czech Republic. Environmental pollution, v.142, p.409-417, 2007. Available from: $<$ http://dx.doi.org/10.1016/j.envpol.2005.10.024>. Accessed: Jan. 28, 2013. doi: 10.1016/j.envpol.2005.10.024.

GUERRA, D.L. et al. Application of Brazilian kaolinite clay as adsorbent to removal of U(VI) from aqueous solution: kinetic and thermodynamic of cation-basic interactions. Journal of Solid State Chemistry, v.183, p.1141-1149, 2010. Available from: $<$ http://dx.doi.org/10.1016/j.jssc.2010.03.021>. Accessed: Jan. 28, 2013. doi: 10.1016/j.jssc.2010.03.021.

MELO, V.F. et al. Chemical and mineralogical properties of kaolinite-rich Brazilian soils. Soil Science Society of America Journal, v.65, p.1324-1333, 2001. Available from: <https://www. soils.org/publications/sssaj/abstracts/65/4/1324>. Accessed: Jan. 28, 2013. doi:10.2136/sssaj2001.6541324x.

PROST, R. et al. Infrared study of structural $\mathrm{OH}$ in kaolinite. dickite. nacrite and poorly crystalline kaolinite at 5 to $600^{\circ} \mathrm{K}$. Clays Clay Minerals, v.37, p.464-468, 1989. Available from: $<$ http://www.clays.org/journal/archive/volume\%2037/37-5-464. pdf>. Accessed: Jan. 28, 2013.

SRIVASTAVA, P. et al. Competitive adsorption behavior of heavy metals on kaolinite. Journal of Colloid and Interface Science, v.290, p.28-38, 2005. Available from: <http://dx.doi. org/10.1016/j.jcis.2005.04.036>. Accessed: Jan. 28, 2013. doi: 10.1016/j.jcis.2005.04.036.

TESSIER, A. et al. Sequential extraction procedure for the speciation of particulate trace metals. Analytical Chemistry, v.51, p.844-851, 1979. Disponível em: <http://pubs.acs.org/ doi/abs/10.1021/ac50043a017>. Accessed: Jan. 28, 2013. doi: $10.1021 / \mathrm{ac} 50043 \mathrm{a} 017$

USMAN, A.R.A. The relative adsorption selectivities of $\mathrm{Pb}, \mathrm{Cu}$, $\mathrm{Zn}, \mathrm{Cd}$ and Ni by soils developed on shale in New Valley. Egypt. Geoderma, v.144, p.334-343, 2008. Available from: <http:/ dx.doi.org/10.1016/j.geoderma.2007.12.004>. Accessed: Jan. 28, 2013. doi: j.geoderma.2007.12.004.

WANG, X.; LI, Y. Measurement of $\mathrm{Cu}$ and $\mathrm{Zn}$ adsorption onto surficial sediment components: New evidence for less importance of clay minerals. Journal of Hazardous Materials, v.189, p.719-723, 2011. Available from: <http://dx.doi.org/10.1016/j. jhazmat.2011.03.045>. Accessed: Jan. 28, 2013. doi: 10.1016/j. jhazmat.2011.03.045.

ZHU, Y. et al. Transport and interactions of kaolinite and Mercury in satured sand media. Journal of Hazardous Materials, v.213/214, p.93-99, 2012. Available from: <http://dx.doi. org/10.1016/j.jhazmat.2012.01.061>. Accessed: Jan. 28, 2013. doi: 10.1016/j.jhazmat.2012.01.061. 